\title{
THE VIRTUAL DIMENSION OF SOCIO-ECONOMIC RELATIONS IN EUROPEAN COUNTRIES
}

\author{
Danuta WITCZAK-ROSZKOWSKA \\ Kielce University of Technology; dwr@xl.wp.pl, ORCID: 0000-00002-1657-8697
}

\begin{abstract}
Purpose: The purpose of the article is to assess the level of use of information technologies by households in selected European countries and the resulting transformations in socio-economic relations.
\end{abstract}

Design/methodology/approach: The article uses one of the taxonomic methods the Hellwig's development pattern method. 20 diagnostic features were adopted to develop Hellwig's synthetic measure. They reflect the access and use of the Internet by households in five areas: networking and formal activities in the fields of e-government, e-banking, e-education, e-health; carrying out political and civic activities online (consulting, voting, expressing opinions); making informal contacts and participating in social networks (e.g. Facebook, Twitter, etc.); e-commerce; using instant messaging and e-mail.

Findings: In the light of the characteristics adopted for the survey, the highest level of use of information technology by households is characteristic of Iceland, Norway, Denmark, Sweden, the Netherlands, Great Britain and Finland. The countries with the lowest rates are Romania and Bulgaria.

Research limitations/implications: The studies presented may contribute to further in-depth analyses of the links between the use of information technologies in individual countries and their level of economic development in the long term.

Originality/value: The results are addressed to public authorities in 30 European countries. On their basis, leaders in the use of information technologies by households in various areas of economic and social life were identified. The distance between the other countries was also diagnosed. The results of the research can guide public authorities in developing strategies for the development and dissemination of information technologies in their countries.

Keywords: information technology, Hellwig's method e-commerce, e-education, society 5.0.

Category of the paper: Research paper.

\section{Introduction}

The intensive development of information technologies is transforming social and economic relations. They take on a virtual character, they become aspatial, asynchronous, 
aphysical and anonymous. Network individualism is spreading, specific types of virtual communities are being created, and a generation of "digital natives", young people born after 2000 , for whom the virtual world is as obvious and common as the real world, is entering the labor market. From here it is only a step towards a society 5.0 - "driven" by imagination and creativity, in which digital reality and real world intermingle and integrate. Society 5.0 is a consequence of technological development and convergence of data processing methods, means of communication and accumulation of knowledge in the implementation of economic processes using electronic means of data exchange and artificial intelligence. These advanced technological solutions "at the service of man" are intended to give us a better life. The society 5.0 model is to be built on the foundation of the existing information society (4.0). However, this transition will not be possible without wide access to and use of information and communication technologies, including the Internet, which constitute the basic market infrastructure.

The purpose of the article is to assess the level of use of information technologies by households in selected European countries and the resulting transformations in socio-economic relations.

The level of information technologies utilization in selected European countries was diagnosed on the basis of Hellwig's development pattern method.

The analysis covered 30 European countries. In pursuing the research objective, attention was paid to the spatial diversity of the level of use of information technologies, with particular emphasis on Poland's position in this area.

\section{Information technologies in human life - challenges, opportunities, threats}

Information technologies enter into every area of human activity, transforming both the environment in which humans function and the human itself. These changes have profound economic, social and psychological dimensions.

A specific, peculiar reflection of the social reality is the family in which the characteristics of a given historical epoch are immortalized, providing an opportunity to assess the state and directions of development of society (Such-Pyrgiel, 2019, p. 123). In this context, the question arises: How has the spread of information technology changed the modern family?

The influence of information technologies on the functioning of modern families is most evident in the loosening of family ties, weakening of the sense of community and popularization of individualism. Urilch Beck stresses that individualism means "living your own life" (Beck, 2004, p. 22). Under these conditions, "the family no longer constitutes a stable reference point. Individuals define and create their own biography individually"(Beck, 2004, p. 22), finding 
support in virtual communities representing similar values, attitudes, interests. Young family members are increasingly "rooted" in a virtual reality that is increasingly competitive with the family. This competition is generally hindered by lower digital competences of parents than children, which limit both the ability to understand and control this reality.

M. Prensky called young people born after 1990, growing up and brought up in a world saturated with information technologies, the "digital natives", emphasizing at the same time that the computer and Internet are for them as natural elements of the world as for the previous generation electricity, radio and televisionwere (Prensky, 2001, pp. 1-6). They use information technologies as tools for entertainment, learning, work and even creating their image. According to J. Morbitzer, the presence of the Internet in their lives is obvious and necessary, while its absence seems to be unimaginable (Morbitzer, 2011, p. 132). This need to be constantly online, combined with the fear that otherwise one will miss the opportunity to participate in cultural, professional, social events is a manifestation of the so-called FOMO syndrome (Fear of Missing Out), which slowly becomes a disease of civilization. FOMO is studied in the context of uncontrolled use of and dependence on various applications (Tomczyk, 2018, pp. 541-549). It is also linked to the negative consequences of using social media, manifested by constant checking for new information (James, Lowry, Wallace, Warkentin, pp. 560-596).

The chronic use of the Internet by young people makes them incapable of "deeper reflection, unable to draw general conclusions or take a broader view" (Small, Vorgan, 2011, p. 45). It destroys their creativity - they memorize a lot of information, but are no longer able to interpret it, approach it critically, make use of it. N. Carr calls this state of affairs "intellectual shallows" (Carr, 2010, p. 24). Despite better and better access to information, young people understand and know less and less, they are less and less brilliant and cannot see the wider context of the phenomena and processes taking place. Their knowledge is fragmented, used without reflection, often on the basis of the "copy, paste" method.

It is also worth noting that in young people, especially children, who abuse the Internet, the brain "[...] disconnects the prefrontal cortex, the part responsible for empathy, altruism and tolerance. As a result, one becomes indifferent to what does not concern one personally" (Nikodemska, 2011, p. 34). Under these conditions, social relations in the real world are disrupted. For young people it becomes problematic to communicate their feelings or to understand someone else's point of view, while in everyday life they act like robots, similarly to autistic people. 


\section{Virtual relationships in the electronic marketplace}

The development and dissemination of information technologies, especially the Internet, has led to the emergence of cyberspace - a virtual space that also transforms the economy. Businesses - companies, households, banks, stock exchanges, etc. - move their activities into cyberspace. Sending information about products and services, about transaction conditions, or finally the finalization of the transaction itself, including making a payment, can be done in virtual space in the so-called electronic market. In some respects, the electronic market is similar to the traditional, conventional one. Similarly, it covers entities, market objects and interconnections that determine demand, supply and price. However, the relationship between these entities is fundamentally changing. There is no personal buyer-seller contact, interactions take place via the Internet, and in the course of concluding transactions, products and services exist as digital information provided by channels based on information technologies (Gregor, Kalińska-Kula, 2018, pp. 110-120). Material products reach the buyer only after the transaction is completed, through logistics and transport services, while those of an intangible nature, e.g. music, film, e-book, are sent using information and communication technologies. At this point the growing interest in the so-called virtual objects of market trading is worth noting. These are physically non-existent visualizations of a computer numerical code. They may be part of the software that makes up a computer game, or possibly a self-contained unit that can function outside the game. In broad terms, these include in-game items, social networking accounts, virtual currency, Internet domains. Thus, a dematerialization of transactional processes, in which intangible goods are increasingly involved, occurs. The high level of information technology development gradually reduces the need for direct human participation in market processes, including transactions.

E-market players have much greater access to various sources of information compared to those operating in a conventional market and can therefore deepen their knowledge with a wide choice of market offers with unlimited space and time availability.

E-market also enables creation of stronger links between its demand and supply side. The purchasers-consumers take over to some extent the functions performed by the producers, becoming the entities creating products and services, the so-called prosumers. The manufacturer provides the consumer with a set of tools that enable him or her to create individualized products. The richer the instruments, the higher the level of consumer involvement in the production process, product individualization, creativity and innovation unleashed in the consumer (Mitręga, Witczak, 2012, pp. 432-444). By involving consumers in the product development process, manufacturers move from so-called passive consumption (where it was enough to design, produce and promote a product to sell it) to the so-called active consumption. This commitment of the consumers is translated into their greater loyalty to the company, the brand they co-create. Consumers become its "ambassadors". This allows the 
manufacturer to maintain them and gain new consumers through them. According to B. Frost, prosumers become external employees of the company, strengthening the innovative potential of companies, participating in building competitive advantage (Mróz, 2010, p. 68).

In this case, the Internet facilitates not only consumer-to-consumer but also consumer-tomanufacturer communication, becoming a tool through which the consumer can participate in the product development process.

According to E. Szul, this is confirmed by much lower consumer activity in the real world than in the virtual one (Szul, 2013, pp. 347-358). "Today's prosumers are mainly people who use new solutions and technologies, whose basic working tools are the computer, Internet, mobile phone" (Szul, 2013, pp. 347-358). Opening up to the client, establishing partnership relations with him or her, engaging his or her creativity for the needs of companies, requires the development of communication platforms allowing prosumers to create individualized products.

\section{Research method}

For research purposes, information technology is defined as "a set of measures (i.e. devices such as computers and computer networks) and tools (including software), as well as other technologies that serve the comprehensive use of information" (Sysło, 2005, p. 50). According to Maciej M. Sysło, it is important to point out the difference between information technology and computer science, although, as the author stresses, the boundaries are sharp in this case. Information technology is related to using ready-made IT products to work with information, e.g. text editor, spreadsheet, browsers, ready-made programs used for communication purposes, creating own pages, blogs etc. Computer science, on the contrary, refers to the creation of new IT "products", i.e. a program or sets of programs written in a selected language or programming environment, a computer problem-solving algorithm, etc. (Sysło, 2005, pp. 50-51).

Hellwig's synthetic indicator determining the level of use of information technologies in 30 selected European countries was developed on the basis of 20 diagnostic features. They reflect the access and frequency of use of Internet networks by households and individuals in the following areas: 1) networking and formal activities in the field of e-government, e-banking, e-education, e-health; 2) carrying out political and civic activities online (consulting, voting, expressing opinions); 3 ) making informal contacts and participating in social networks (e.g. Facebook, Twitter, etc.); 4) e-commerce; 5) using instant messaging and e-mail (Table 1).

The study showed a moderate degree of country variation in terms of the value of diagnostic features. The coefficient of variation reflecting it ranged from $6.9 \%$ to $81.6 \%$. European countries show a similar level of household access to the Internet. The coefficient of variation for this diagnostic feature had the lowest value. The greatest number of households with Internet 
access was recorded in three countries: the Netherlands, Norway and Iceland $(98 \%$ in all countries). In the case of the Netherlands, it was entirely broadband Internet access. The smallest number of households with Internet access was in Bulgaria (75\%) and Greece (79\%). In Poland $87 \%$ of households declared access to the Internet, in the case of $83 \%$ it was broadband Internet. The greatest diversity of European countries concerned the use of the Internet for financial activities, i.e. buying or selling shares, bonds or investment services, renewing existing policies, etc. The most active in this area were citizens of the UK, Sweden. The value of this diagnostic feature was $56 \%$ and $50 \%$ respectively. Romania was at the opposite end in terms of this activity, only $2 \%$ of respondents declared using the Internet for the above mentioned purpose.

Table 1.

Diagnostic features adopted in the own study

\begin{tabular}{|c|c|}
\hline No. & Name of the diagnostic feature \\
\hline \multicolumn{2}{|r|}{ Internet access and use } \\
\hline 1. & Internet access in households \\
\hline 2. & Access to broadband Internet in households \\
\hline 3. & Daily computer use by individuals \\
\hline \multicolumn{2}{|r|}{$\begin{array}{l}\text { Establishing contacts and carrying out formal activities in the field of e-administration, e-banking, } \\
\text { e-education, e-health }\end{array}$} \\
\hline 4. & Individuals using the Internet for electronic banking \\
\hline 5. & Individuals using the Internet to do an online course in different subjects \\
\hline 6. & Individuals using the Internet to make an appointment with a doctor through the website in 2018 \\
\hline 7. & $\begin{array}{l}\text { Individuals using the Internet to obtain information from public authorities' websites in the last } 12 \\
\text { months }\end{array}$ \\
\hline 8. & Individualsusing the Internet to send documents to public authorities in the last 12 months \\
\hline \multicolumn{2}{|r|}{ E-commerce } \\
\hline 9. & Individuals using the Internet to obtain information about products and services \\
\hline 10. & Individualsusing the Internet to sell products or services \\
\hline 11. & $\begin{array}{l}\text { Individualswho have carried out one or more financial activities over the Internet (i.e. bought or sold } \\
\text { shares, bonds or investment services, renewed existing policies, etc.) }\end{array}$ \\
\hline 12. & Individuals who have made purchases over the Internet in the last 3 months \\
\hline \multicolumn{2}{|r|}{ Informal networking and participation in social networks } \\
\hline 13. & $\begin{array}{l}\text { Individuals using the Internet to participate in social networks (creating a user profile, publishing } \\
\text { messages or other content on Facebook, Twitter, etc.) }\end{array}$ \\
\hline 14. & Individuals using the Internet to upload self-created content to any website for sharing in 2019 \\
\hline 15. & Individuals who used the cloud services, i.e. saved text documents, photos, music, films or other files \\
\hline \multicolumn{2}{|r|}{ Use of instant messaging and e-mail } \\
\hline 16. & Individualsusing the Internet to send or receive e-mail \\
\hline 17. & Individuals using the Internet to make telephone calls and video calls \\
\hline 18. & Individuals using the Internet to send instant messages e.g. via Skype, Messenger, WhatsApp, Viber \\
\hline \multicolumn{2}{|r|}{ Political and civic activities } \\
\hline 19. & $\begin{array}{l}\text { Individuals using the Internet for online consultation or voting on civil or political matters (e.g. urban } \\
\text { planning, signing a petition) }\end{array}$ \\
\hline 20. & $\begin{array}{l}\text { Individuals using the Internet to publish opinions on civic or political issues through websites } \\
\text { (e.g. blogs, social networks) }\end{array}$ \\
\hline
\end{tabular}

Source: Own elaboration. 
Based on the Hellwig's synthetic measure value, four groups of European countries with different levels of IT use were identified. These are accordingly:

group I - countries with the highest IT use indicator, where $d_{i} \geq \bar{d}_{\imath}+S_{d i}$,

group II - countries with an average IT use indicator, where $\bar{d}_{\iota} \leq d_{i}<\bar{d}_{\imath}+S_{d i}$,

group III - countries with a low IT use indicator, where $\bar{d}_{\imath}-S_{d i} \leq d_{i}<\bar{d}_{l}$,

group IV - countries with the lowest IT use indicator, where $d_{i}<\bar{d}_{\imath}-S_{d i}$,

where:

$d_{i}$ - value of the synthetic indicator,

$\overline{d i}-$ average value of the synthetic indicator $d_{i}$,

$\mathrm{S}_{d i}-$ standard deviation of the indicator $d_{i}$.

\section{Research results}

Seven countries are characterized by the highest level of information technology use, i.e. Iceland, Norway, Denmark, Sweden, the Netherlands, the United Kingdom and Finland (cf. Table 2). Another group of seven countries (Estonia, Luxembourg, Spain, Germany, Malta, Ireland, Belgium) has an average level of IT use (cf. Table 2). The most numerous group of countries, including Poland, are those with low levels of IT use (cf. Table 2).

Table 2.

Ranking of European countries by the value of the Hellwig's synthetic indicator on the level of use of information technology in households (2019)

\begin{tabular}{|l|l|l|r|}
\hline No. & Country & Hellwig's synthetic measure value & \\
\hline \multicolumn{3}{|l|}{ Countries with the highest IT use } \\
\hline 1. & Iceland & & 0.747 \\
\hline 2. & Norway & & 0.709 \\
\hline 3. & Denmark & & 0.707 \\
\hline 4. & Sweden & & 0.664 \\
\hline 5. & Netherlands & & 0.612 \\
\hline 6. & United Kingdom & & 0.610 \\
\hline 7. & Finland & & 0.590 \\
\hline & & & 0.557 \\
\hline 8. & Estonia & & 0.481 \\
\hline 9. & Luxembourg & & 0.464 \\
\hline 10. & Spain & & 0.460 \\
\hline 11. & Germany & & 0.447 \\
\hline 12. & Malta & & 0.439 \\
\hline 13. & Ireland & & 0.383 \\
\hline 14 & Belgium & & \\
\hline
\end{tabular}


Cont. table 2.

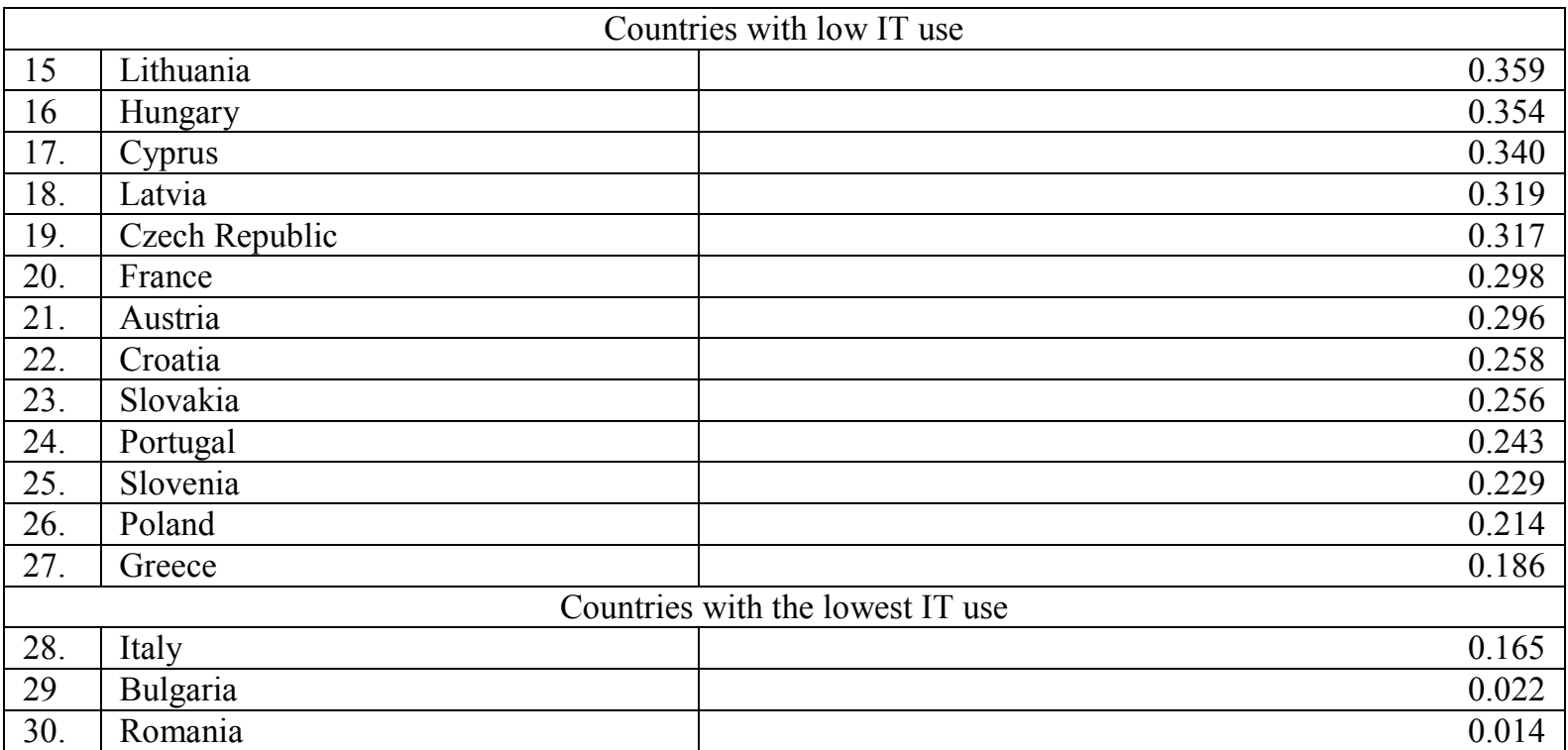

Source: Own elaboration.

Italy, Bulgaria and Romania are the three countries with the lowest level of IT use in households (cf. Table 2). It should be stressed, however, that in this group Italy is characterized by nearly 12 times higher value of Hellwig's synthetic measure than Romania and 7.5 times higher than Bulgaria. Romania has the lowest position in the ranking of countries surveyed. The value of the synthetic measure is more than 53 times lower for this country than for the ranking leader, Iceland.

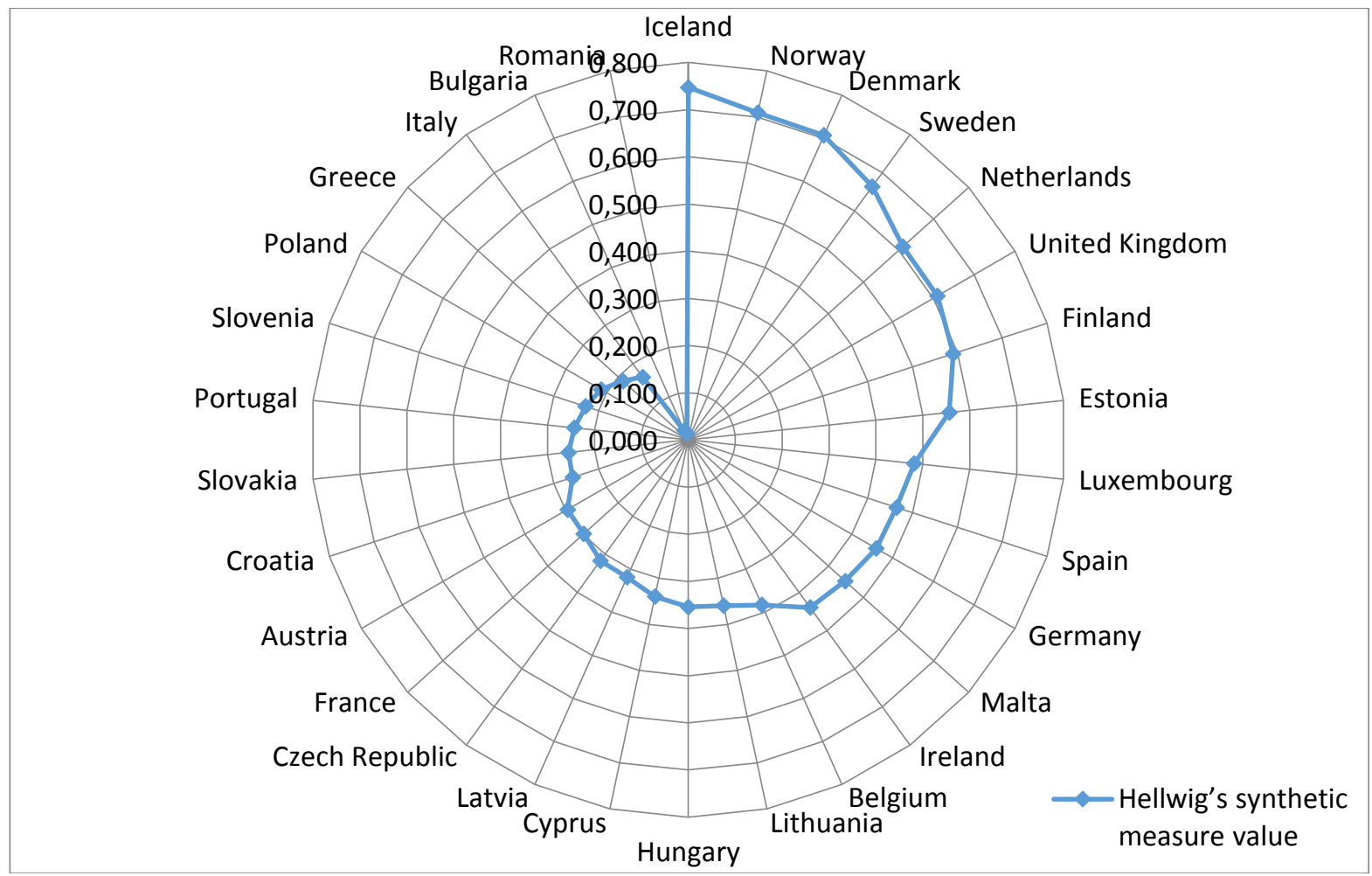

Figure 1. Differentiation of European countries in terms of the level of use of information technologies by households in 2019 (based on the value of Hellwig's synthetic indicator). Source: Own elaboration. 
The further part of the article focuses in particular on the analysis of the level of use of information technologies in various areas of households in Poland, diagnosing those with a relatively low and high level of use of Internet networks, especially against the background of leaders in this area.

The value of all diagnostic features characterizing the level of use of information technologies in Poland is lower than their arithmetic mean for the countries covered by the survey.

Poles relatively rarely use cloud services, i.e. saving text documents, photos, music, films or other files. This is a type of service that consists of storing data on an external server of the service provider. It can be described as a so-called virtual portable drive. The user of this service has constant access to its content, from virtually every place where the Internet is accessible. Only $21 \%$ of Poles covered by the survey declared the use of cloud, which placed Poland penultimate in the ranking of European countries. A smaller percentage of this service users was only in Bulgaria (18\%). The leaders in this area were Sweden and Iceland, where $63 \%$ of respondents declared using this IT solution.

Social media, thanks to their universal accessibility, subject only to social control, speed of information provision and ease of interaction, are an increasingly intensively used platform for the dissemination of various types of content - from text to film. Poles, compared to other countries, use them relatively rarely. Although in 2019 as many as 52\% of respondents from Poland declared creating user profiles, publishing messages or other content on Facebook, Twitter, etc., it was nearly $40 \%$ less than the leader of the ranking in this respect - Iceland. The activity of Poles in submitting self-created content to any website for sharing was also relatively low. It was declared by $21 \%$ of respondents. Iceland was once again the leader here, with more than three times higher value of this indicator. In turn, Poles are distinguished by their activity in publishing opinions on civic or political issues through websites - blogs, social networks, etc. In 2019, 12\% declared activity in this area, which gave Poland 13th position in terms of the value of this diagnostic feature. In the case of the ranking leader, Denmark, this declaration was made by $20 \%$ of the respondents. Unfortunately, Poles are much less active in this field when they are to use the Internet to engage in civic or political issues, e.g. take part in on-line consultations or vote on issues related to urban planning, signing a petition, etc. Only $6 \%$ of respondents took up such activity. The leader of the ranking in this case was Estonia, where $26 \%$ of citizens were active in this respect.

Virtual relations are increasingly displacing face to face contacts in the formal areas of human life, i.e. administration, banking, education and health care. This also applies to Poland, although these processes are much less advanced in Poland than in Norway, Finland, Denmark or Iceland. Poles most often declare the use of the Internet for electronic banking and sending documents to public authorities. In the first case, such activity was declared by nearly $47 \%$ of respondents, while in the second case $-31 \%$. The leader of the ranking in the area of e-banking was Norway, where $95 \%$ of respondents reported using it. Iceland was the leader in virtual 
contacts with the administration, especially as regards sending various types of documents to public authorities. This form of contact was used by $80 \%$ of Icelanders, and $31 \%$ of Poles. The use of the Internet in e-education and e-health is relatively less developed. This is confirmed by statistical data on the participation e.g. in online courses or arranging medical appointments online. The Internet in this respect was used by 5\% and 10\% of Poles respectively. The country with the most developed virtual relations in these areas was Finland, for which these rates were $21 \%$ and $44 \%$ respectively.

The Internet is an attractive channel for the distribution of goods and services, mainly due to its global reach, ease of use as well as multimedia and interactivity. Both the number of e-buyers, also called digital buyers (Tarczydło, 2016, pp. 317-326), and e-shops is growing rapidly.

Poles willingly use the Internet to obtain information about products and services $(62 \%$ of respondents), but they declare to make purchases in this form a little less frequently (41\%). The Internet is most often used for shopping by households in the UK (80\%) and Denmark (74\%), and least frequently in Romania (15\%) and Bulgaria (14\%). Compared to European countries, Poles relatively often sell products and services online. In 2019, 14\% of those surveyed declared activities in this area, which placed Poland on 19th position among 30 surveyed. The leader in this area was the Netherlands (36\%) and Norway (33\%).

It is worth noting at this point that Poland is one of the European countries where the e-commerce market is growing extremely dynamically. Its growth rate is $18 \%$ per year. In 2001 , the value of the e-commerce market was estimated at PLN 0.1 billion, while at the end of 2018 it exceeded PLN 51 billion (Report, Cushman and Wakefild, 2019). The share of the value of Internet sales in the total retail trade in Poland is $4.3 \%$, compared to $17 \%$ in the UK (Report, Cushman and Wakefild, 2019). The European e-commerce channel is estimated to be worth $€ 602$ billion. Nearly $60 \%$ of turnover is generated by just three markets, i.e. British, French and German. The share of Poland is at the level of 2\% (Report, Cushman and Wakefild, 2019). In the light of the above mentioned indicators, it can be concluded that the development potential of the e-commerce market in Poland is high. It is also supported by the fact that digital buyers in Poland are mainly young people (up to 34 years of age), with secondary or higher education, who are in a relatively good financial situation (Report, Gemius for e-Commerce Polska, 2019).

\section{Final thoughts}

The development and dissemination of information technologies is transforming the existing social and economic processes, creating a number of opportunities, but also bringing many risks. The Internet, offering new forms of communication, interpersonal interaction, 
cooperation, enters all areas of human functioning, transforming the lifestyle. This kind of e-life style is characterized by limiting contacts in the real world and transferring them to the virtual world. Under constant time pressure due to increasing educational and professional requirements, etc. the virtual world with its aspatial and asynchronous nature is an attractive alternative to the real world, a platform for establishing informal and formal contacts by contemporary man.

In 1992, Jaron Lanier stated that virtual reality cannot exist without a social context; it will gain cultural and spiritual value only if it becomes popular and the number of its users increases (Lanier, 1992, p. 150). Today, nearly 30 years after the Lanier wrote this article, it can be said that virtual reality has gained such value, and virtual communities offer common values, ties, interests, support and friendship. M. Castells noted that human relationships are clearly evolving (Castells, 2003, p. 85). The importance of relationships within the family as well as the local community and associations is diminishing, while that of online relationships that people form around them, guided by a sense of similarity rather than spatial proximity, is growing. The development of information technology is of key importance in this case, as it makes it possible to break through spatial limitations. The Internet and relevant information technologies make people more and more often transfer various activities from the real world to cyberspace. They shop there, look for information, knowledge, entertainment, make acquaintances and even friends. Can we therefore state with certainty that the development and spread of information technologies has led to the creation of a new type of community called virtual one?

If we define a community as "a network of human bonds that is a source of social life, support, information, sense of belonging and social identity" (Wellman, Gulia, 1997, pp. 1-27) then an answer to this question would be positive. Virtual communities are a new type of community, for which it is characteristic to build relationships based on similarities in behavior, values, views, etc. and to participate in many networks connected by weak ties.

The results of own research have shown that European countries show a diversity in the level of use of information technologies by households, thus also in terms of the development of virtual communities. This process is most advanced in Iceland and Norway and least advanced in Romania and Bulgaria. Households in economically highly developed countries with a relatively high GDP per capita are much more likely to move their professional, shopping, social, cultural and educational activities, and even those related to health care, to virtual space. It can be hypothesized that this allows them to better manage their leisure and working time according to their preferences. It allows a more comfortable life, it is a response to the increasing pace of life and the pressure of time. Information technologies provide an opportunity to better reconcile everyday duties - professional work, childcare, household management, learning, with the need to establish interpersonal relationships, membership, acceptance, social recognition. However, there are serious risks arising here, mainly due to man's overwhelming "immersion" in the virtual world, his/her delight in it and thoughtless use 
of information technologies. The Internet addiction syndrome, voluntary removal of privacy by "flooding" social networking sites with information from personal life, cyberbullying, are just some of these threats. How to eliminate them? It seems impossible to eliminate them completely, but they can be reduced.

Modern man must have the ability to use information technologies effectively in his or her professional and private life, and must also have the ability to use them prudently, not violating the dignity and rights of other people, without destructing his or her own psyche. Risks can be reduced only if one combines these skills. Education has an important role to play in this respect, first and foremost humanistic education, not the technical-informational one, focused on learning to use a computer, various programs, etc. It is hard to disagree with the words of J. Morbitzer, who stated that technical sciences provide tools, but the answers to questions about their worthy use should be sought in the area of humanities (Castells, 2003). Unfortunately, this area of education is still underestimated and poorly present in curricula.

At this point, it is worth noting the special case of the use of information technologies dictated by external factors, which forced the transfer of professional, educational and social activities to the Internet. This is the situation we are dealing with now, when as a result of the coronavirus COVID-19 pandemic, forced isolation and radical reduction of society's activity in the real world were ordered. In this specific situation, the use of information technology has prevented complete paralysis of socio-economic life. The need, or even the obligation, to work, educate and socialize remotely for many months will not be without influence on the further spread of information technologies in households, businesses, administrations, banks, etc. It seems that this, forced by the situation, long-term contact with the Internet, various tools of remote work and communication, will contribute to breaking down mental barriers related to fears of these technologies and will increase the level of competence in handling them, especially in older people. The question remains open - To what extent will the situation contribute to the development of virtual social and economic relations in Poland and what will be the consequences?

\section{References}

1. Alt, D. (2107). Students' social media engagement and fear of missing out (FoMO) in a diverse classroom. Journal of Computing in Higher Education, 29(2), pp. 388-410.

2. Beck, U. (2004). Społeczeństwo ryzyka. W drodze do innej nowoczesności. Warszawa: Wydawnictwo Scholar.

3. Carr, N. (2010). The Shallows: What the Internet Is Doing to Our Brains. New York: W.W. Norton\&Company. 
4. Castells, M. (2003). Galaktyka Internetu: refleksje nad Internetem, biznesem i społeczeństwem. Poznań.

5. E-commerce $w$ Polsce 2019. Gemius for e-Commerce Polska, https://eizba.pl/wpcontent/uploads/2019/07/raport_GEMIUS_2019-1.pdf.

6. Gregor, B., Kalińska-Kula, M. (2108). Rozwój handlu internetowego i jego uwarunkowania - perspektywa oferenta i nabywcy. Handel Wewnętrzny, 4(375), pp. 110-120.

7. James, T.L., Lowry, P.B., Wallace, L., \& Warkentin, M. (2017). The effect of belongingness on obsessive-compulsive disorder in the use of online social networks. Journal of Management Information Systems, 34(2), pp. 560-596.

8. Lanier, J. (1992). An Insider's View of the Future of Virtual Reality. Journal of Communication, vol. 42, http://www.mindlab.org/images/d/DOC812.

9. Mitręga, M., Witczak, O. (2012). Prosumpcja jako przejaw przedsiębiorczości konsumenckiej. Ekonomiczne problemy ustug, 97(724), pp. 432-444.

10. Morbitzer, J. (2011-2012). O istocie medialności młodego pokolenia. Neodidagmata, 33/34. Poznań.

11. Mróz, B. (2010). Nowe trendy konsumenckie - szansa czy wyzwanie dla marketing. Marketing $w$ realiach współczesnego rynku. Implikacje otoczenia rynkowego. Sz. Figiel (ed). Warszawa: PWE.

12. Nikodemska, J. (2011). Jak nas psuje Facebóg. Focus, No. 2/185 (February), p. 34.

13. Prensky, M. (2001). Digital Natives, Digital Immigrants. From On the Horizon. MCB University Press, Vol. 9, No. 5, pp. 1-6.

14. Raport (2019). Jak ugryźć e-commerce $w$ magazynie. Cushman and Wakefild, https://media.pl.cushmanwakefield.com.pl/pr/444970/deweloperzy-magazynowi-ioperatorzy-logistyczni-sa-zgodni-e-commerce-r.

15. Small, G., Vorgan, G. (2011). iMózg. Jak przetrwać technologiczna przemiane wspótczesnej umysłowości. Poznań: Wyd. Vesper.

16. Such-Pyrgiel, M. (2019). Człowiek w dobie cyfrowej transformacji. Toruń: A. Marszałek.

17. Sysło, M. (2005). Rozwój technologii informacyjnej a edukacja - stan, kierunki, wyzwania. Holistyczne $i$ analityczne metody diagnostyki edukacyjnej. Perspektywy informatyczne egzaminów szkolnych. B. Niemierko, G. Szyling (eds.). Gdańsk: Fundacja Rozwoju Uniwersytetu Gdańskiego.

18. Szul, E. (2013). Prosumpcja jako aktywność współczesnych konsumentów uwarunkowania i przejawy, Nierówności Społeczne a Wzrost Gospodarczy, No. 31, Rzeszów.

19. Tarczydło, B. (2016). Nabywca digitalny a skuteczne działania marketingowe - wybrane aspekty. Studia i Prace Wydziału Nauk Ekonomicznych i Zarzadzania Uniwersytetu Szczecińskiego, No. 43/6. 
20. Tomczyk, Ł., Selmanagic-Lizde, E. (2018). Fear of Missing Out (FOMO) among youth in Bosnia and Herzegovina-Scale and selected mechanisms. Children and Youth Services Review, 88, pp. 541-549.

21. Wellman, B., Gulia, M. (1997). Net Surfers Don't Ride Alone: Virtual Communities as Communities. New York, http://www.chass.utoronto.ca/-wellman/publications/ netsurfers.pdf. 